\title{
Financing pro-ecological investments in the Częstochowa municipal enterprise
}

\author{
Magdalena Wrońska ${ }^{1,2, *}$, Anna Kwarciak-Kozłowska ${ }^{1}$, Katarzyna Długosz ${ }^{1}$, \\ and Monika Galwa-Widera ${ }^{2}$ \\ ${ }^{1}$ Czestochowa Municipal Enterprise, Konwaliowa 1 Sobuczyna, 42-263 Wrzosowa, Poland \\ ${ }^{2}$ Czestochowa University of Technology, Faculty of Infrastructure and Environment, \\ Dąbrowskiego 73, 42-201 Czestochowa, Poland
}

\begin{abstract}
The paper presents the opportunities for funding ecological investments with the example of the Czestochowa Municipal Enterprise. Modernizations of facilities and technologies are usually very capitalintensive investments. High costs of operation and changes introduced to programs of waste management have stimulated creation of various forms of support for the enterprises, including companies involved in municipal waste management. Both Poland and the European Union provide financial support to enterprises for ecological and innovative purposes. For nearly 15 years, both national and international programs have offered their support for changes in the system of waste management. The Czestochowa Municipal Enterprise has been successful in meeting legal requirements. Subsidies from the EU operational programs (nearly a third of investments in 2004-2014) allowed for the achievement of a high level of investments. One should emphasize performance of such tasks as municipal waste sorting plant, composting facility, station of bulky waste disassembly, station of construction debris fragmentation or municipal point of dangerous waste collection. 200 points of selective waste collection have been created in the community and educational campaigns were performed concerning waste sorting. Each of these units represents a necessary component of modern and ecological waste management. Nowadays, waste landfills represent modern enterprises with huge economic potential, whereas investments and subsidies allow for the development and building infrastructure of the municipal industry which is essential in development of cities and villages.
\end{abstract}

\section{Introduction}

The statistical Pole produces about $303 \mathrm{~kg}$ of waste per year (GUS 2016 data), which means that Poland is the only one of the largest waste producers in the EU. Paradoxically, looking at the level of waste generated by the inhabitants of the western EU countries, who produce about $200 \mathrm{~kg}$ more waste, it can be concluded that in Poland waste is not a problem and its proper management. This disproportion may result from differences in the level of economic development and the fact that only $80 \%$ of Polish households are included in the

* Corresponding author: magdalena.wronska90@gmail.com 
system of organized waste collection. According to the Eurostat data for the EU countries, only $38 \%$ of waste reaches the landfills, whereas the rest is burnt, recycled or composted. Unfortunately, most of the waste in Poland is stored using conventional methods $[1,2]$. The Act of 14 December 2012 on waste (Journal of Laws 2013, Pos. 21 with further amendments) imposes the obligation of updating voivodship waste management plans with the development of investment plans. Their aim is to indicate the infrastructure necessary for the achievement of the conformance to the directives of the European Union (e.g. 2008/98/EC and 1999/31/EC) concerning municipal waste management, including implementation of hierarchy of the methods to manage the waste and reach the required levels of preparation for recycling and reusing the waste and limitation of storage of biodegradable municipal waste [1-4]. This imposes the obligation of continuous modernization and extension on the waste management enterprises. The expenditures for ecological investments often exceed the annual budgets of the beneficiaries. Therefore, the investments in modern ecological technologies would be impossible without various forms of support, both from national funds, EU funds and foreign subventions i.e. the Norwegian Financial Mechanisms or the European Economic Area Financial Mechanism [3].

\subsection{Waste management in the Silesian Voivodship in Poland}

The key objective of the National Waste Management Plan (Kpgo2022) is to determine waste management policy consistent with hierarchy of waste management and the polluter pays principle. The main objectives include e.g.:

- reduction in waste generation,

- reduction in the amount of biodegradable municipal waste disposed in landfills so that not more than 35\% of the mass of such waste will be stored in 2020 compared to 1995 .

- striving for reduction in the among of waste stored,

- $\quad$ achievement of the required level of recycling and preparation for the renewed use of paper, metal, plastics and glass from the stream of municipal waste.

- increased contribution of the waste subjected to recycling processes [2, 5].

The main environmental problems of the Silesian Voivodship include e.g. poor air quality, insufficient quality of surface and underground waters, soil pollution, burden of the communication noise and poorly organized waste management. The scale of phenomena which have a negative effect in the natural environment in community of the Silesian Voivodship is incomparably higher than in other country regions. The Silesian Voivodship is the 14th biggest voivodship in Poland and the 2 nd in terms of population. The voivodship is characterized by the highest population density (372 people per square metre, with the country's mean of 123 people per square metre) $[2,5]$. It should be noted that the consequence of the achievement of the high level of urbanization and industrial development is irreversible transformations in the natural environment $[2,5]$. The Silesian Voivodship Council (council is a provincial-level elected assembly) of 24 April 2017 concerning the adoption of the Waste Management Plan for 2016-2022 divided the Silesian Voivodship into three municipal waste management regions (RGOK). Four RGOKs were present in previous years. The plan defines activities according to the hierarchy of managing the waste to achieve the objectives determined in the National Waste Management Plan [2]. The Czestochowa Municipal Enterprise is located in the area of the waste management region I. Based on the waste management plan for the Silesian Voivodship, Table 1 presents the municipal waste mass, including biodegradable waste mass for individual regions of municipal waste management. 
Table 1. Vehicles dimensions

\begin{tabular}{|c|c|c|c|c|c|}
\hline Specification & Region I & Region II & Region III & Region IV & $\begin{array}{c}\text { region: } \\
\text { śląskie } \\
\text { voivodeship }\end{array}$ \\
\hline Population, [Os] & 705194 & 2021124 & 1004219 & 762056 & 4492593 \\
\hline $\begin{array}{c}\text { Mass of municipal } \\
\text { waste, [Mg] }\end{array}$ & 204174 & 688930 & 377737 & 227314 & 1498156 \\
\hline $\begin{array}{c}\text { Mass of municipal } \\
\text { biodegradation } \\
\text { solid waste, [Mg] }\end{array}$ & 101115 & 347289 & 188288 & 112943 & 749636 \\
\hline $\begin{array}{c}\text { Generic production } \\
\text { index, [kg/M/year] }\end{array}$ & 290 & 341 & 376 & 298 & 334 \\
\hline
\end{tabular}

\subsection{Sources of financing waste management}

Sources of financing pro-ecological investments in waste management can be divided into three groups (table 2):

- co-financing from Polish funds,

- co-financing from European Union funds,

- co-financing from foreign funds.

The Operational Programme: Infrastructure and the Environment represents an important instrument of implementation of the new Lisbon strategy. Expenditure on priority objectives of the EU accounts for $67.89 \%$ of total expenditure from EU funds. Total amount of financial resources involved in the Operational Programme: Infrastructure and the Environment for the years 2007-2013 was 37.7 billion EUR, of which the EU contribution was 28.3 billion euro, whereas the national contribution was 9.4 billion euro. The most capital-intensive environmental investments in the area of water, wastewater and waste management could be made with the EU subsidies reaching $85 \%$ [1].

Table 2. Sources of financing waste management [7-10]

\begin{tabular}{|c|c|c|}
\hline Sources of funding & Target, mission & $\begin{array}{l}\text { The method of } \\
\text { co-financing }\end{array}$ \\
\hline \multicolumn{3}{|c|}{ National funds } \\
\hline $\begin{array}{l}\text { Funds for environmental protection and } \\
\text { water management } \\
\text { - National Fund for Environmental } \\
\text { Protection and Water Management (existing } \\
\text { since 1989), } \\
\text { - } 16 \text { provincial funds for environmental } \\
\text { protection and water management, }\end{array}$ & $\begin{array}{l}\text { Supporting environmental } \\
\text { actions in the main priorities: } \\
\text { - Protection and sustainable } \\
\text { management of water } \\
\text { resources } \\
\text { - Rational waste management } \\
\text { and protection of the earth's } \\
\text { surface } \\
\text { - Atmosphere protection } \\
\text { - Protection of biodiversity } \\
\text { and ecosystem services }\end{array}$ & $\begin{array}{lr}\text { Subsidies } & \text { and } \\
\text { loans } & \text { on } \\
\text { preferential terms }\end{array}$ \\
\hline BOŚ (Bank of Environmental Protection) & $\begin{array}{l}\text { The goals are closely related } \\
\text { to NFOSiGW operational } \\
\text { programs }\end{array}$ & $\begin{array}{l}\text { Preferential loans } \\
\text { granted on the } \\
\text { basis of the } \\
\text { NFOŚiGW }\end{array}$ \\
\hline \multicolumn{3}{|c|}{ EU funds } \\
\hline $\begin{array}{l}\text { Operational Program Infrastructure and } \\
\text { Environment }\end{array}$ & $\begin{array}{l}\text { - Decrease in the emissivity of } \\
\text { the economy }\end{array}$ & $\begin{array}{l}\text { Refunds (up to } \\
100 \% \text { of costs } \\
\text { incurred) }\end{array}$ \\
\hline
\end{tabular}




\begin{tabular}{|c|c|c|}
\hline Sources of funding & Target, mission & $\begin{array}{l}\text { The method of } \\
\text { co-financing }\end{array}$ \\
\hline & $\begin{array}{l}\text { - Environmental protection, } \\
\text { including adaptation to } \\
\text { climate change } \\
\text { - Improving energy security } \\
\text { - Development of low- } \\
\text { emission public transport in } \\
\text { cities } \\
- \text { Development of rail } \\
\text { transport in Poland }\end{array}$ & $\begin{array}{l}\text { advance } \\
\text { payments }\end{array}$ \\
\hline Operational Program Innovative Economy & $\begin{array}{l}\text {-Increasing the innovativeness } \\
\text { of enterprises } \\
\text { - Increased competitiveness of } \\
\text { Polish science } \\
\text { - Increasing the role of science } \\
\text { in economic development } \\
\text { - Increasing the share of } \\
\text { innovative products of the } \\
\text { Polish economy in the } \\
\text { international market } \\
\text { - Creating sustainable and } \\
\text { better jobs } \\
- \text { Increase in the use of } \\
\text { information } \\
\text { communication technologies } \\
\text { in the economy }\end{array}$ & $\begin{array}{ll}\text { Refunds } & \text { or } \\
\text { advances }\end{array}$ \\
\hline Intelligent Development Program & $\begin{array}{l}\text { - Support for conducting B \& } \\
\mathrm{R} \text { works by enterprises } \\
\text { - Supporting the environment } \\
\text { and the potential of } \\
\text { enterprises to conduct B \& R } \\
\& \text { I activity } \\
\text { - Increasing the intensity of } \\
\text { cooperation within the } \\
\text { national innovation system } \\
\text { - Innovation support in } \\
\text { enterprises } \\
\text { - Increasing the scientific and } \\
\text { research potential }\end{array}$ & $\begin{array}{l}\text { Refunds } \\
\text { advances }\end{array}$ \\
\hline Regional Operational Programs & $\begin{array}{l}\text { - counteracting and } \\
\text { minimizing the effects of } \\
\text { extreme climatic events, } \\
\text { - early response systems in } \\
\text { case of catastrophic events, } \\
\text { - projects related to waste } \\
\text { management, } \\
\text { - projects in the field of } \\
\text { wastewater management and } \\
\text { water supply, } \\
\text { - nature protection, especially } \\
\text { in protected areas. }\end{array}$ & $\begin{array}{ll}\text { Loans } & \text { and } \\
\text { subsidies } & \end{array}$ \\
\hline \multicolumn{3}{|c|}{ Foreign funds } \\
\hline $\begin{array}{l}\text { Norwegian Financial Mechanism } \\
\text { And } \\
\text { Financial Mechanism of the European } \\
\text { Economic Area }\end{array}$ & $\begin{array}{l}\text { - biodiversity and } \\
\text { environmental monitoring } \\
\text { - energy saving and renewable } \\
\text { sources }\end{array}$ & Subsidies \\
\hline
\end{tabular}




\begin{tabular}{|c|c|c|}
\hline Sources of funding & Target, mission & $\begin{array}{l}\text { The method of } \\
\text { co-financing }\end{array}$ \\
\hline & $\begin{array}{l}\text { - research and scholarships } \\
\text { - innovations in the field of } \\
\text { green technologies in } \\
\text { addition, general programs } \\
\text { such as } \\
\text { - civil society } \\
\text { - social and regional } \\
\text { development } \\
\text { - cultural heritage } \\
\text { - decent work and tripartite } \\
\text { dialogue } \\
\text { - Schengen and internal affairs }\end{array}$ & \\
\hline \multicolumn{3}{|c|}{ Other } \\
\hline Commercial bank loans & $\begin{array}{l}\text { Any investments to improve } \\
\text { or change technology, } \\
\text { structure, etc. }\end{array}$ & Credits and loans \\
\hline Own funds of enterprises & $\begin{array}{l}\text { Any investments to improve } \\
\text { or change technology, } \\
\text { structure, etc. }\end{array}$ & $\begin{array}{l}\text { Funds from } \\
\text { commercial } \\
\text { activity - profits }\end{array}$ \\
\hline Municipal budgets & $\begin{array}{l}\text { Pro-ecological investments } \\
\text { within the commune }\end{array}$ & $\begin{array}{l}\text { Financing or co- } \\
\text { financing of } \\
\text { investments or } \\
\text { taking up shares } \\
\text { in investments as } \\
\text { indirect actions }\end{array}$ \\
\hline Private investors & $\begin{array}{l}\text { Ecological and innovative } \\
\text { activities }\end{array}$ & $\begin{array}{l}\text { Co-financing, co- } \\
\text { financing, } \\
\text { sponsorship, }\end{array}$ \\
\hline
\end{tabular}

\subsection{The ecological investments in the area of the Czestochowa Municipal Enterprise}

Czestochowa Municipal Enterprise. in Sobuczyna implemented the investments connected with building the waste management plant within the Integrated Operational Programme for Regional Development. Its net cost was 20,0 million PLN. With additional funding, the following investments were made:

- Municipal waste sorting plant: (current capacity: $95000 \mathrm{Mg} /$ year). Municipal waste sorting plant - the basic task of the sorting plant is separation from the entire stream as much as possible of waste, re-usable. The remaining part, unsuitable for recovery, is transferred for further processing in case of high energy calorific value and in the case of low calorific value of depositing on the component inventory.

- Waste composting plant in the open-prism system (current capacity $40100 \mathrm{Mg}$ /year) Composting is an aerobic treatment of waste, the process takes place in open, aerated piles. In the aerobic prisms, composting occurs on the surfaces of moist and aerated components due to the participation of microorganisms, such as bacteria and fungi. Intensive growth of thermophilic bacteria and high temperature $\left(>70^{\circ} \mathrm{C}\right)$ cause the destruction of parasitic and pathogenic organisms and plant seeds, and as a result, the emergence of compost. Compostable waste is directed to the composting plant: the "bio" fraction from municipal waste, so-called waste. green (leaves, grass), waste trees and shrubs with clipping, other wooden waste, organic and green waste from marketplaces.

- The demolition station for large-size waste (current capacity of $25000 \mathrm{Mg} / \mathrm{year}$ ), such as: furniture, doors, etc. - both waste separated on a sorting line from municipal waste 
and waste collected selectively. On the square, they are dismantled and recovered raw materials that can be re-used (including plastic, metal, wood).

- Station for grinding construction debris (current issue of $15000 \mathrm{Mg} /$ year)Station for shredding renovation and construction waste. There are such waste as: rubble, waste from building renovation, window joinery, etc. The recovery process of the waste provided includes segregation, disassembly, debris crushing, which is later used as a foundation for technological roads.

- Municipal hazardous waste collection point. Including hazardous waste storage. Mobile point of scraps of hazardous waste (MPZON) is a specialized car that hears the collection of hazardous waste from the city of Czestochowa. Collected wastes are temporarily stored in the area of ZZO in Sobuczyna and are then transferred for utilization or processing.

Funding from the Cohesion Fund within the Operational Programme: Infrastructure and Environment with net value of 17,8 million PLN (total value of the investment: 54,5 million PLN) allowed for technological extension of the Regional Installation of Municipal Waste Processing to meet the European standards. The physical execution status of the project was ca. $38.52 \%$, whereas financial progress status was ca. $14.84 \%$. The project included three investment tasks:

- Technical closing of the landfill cell No 1: the task was aimed to seal the top parts and slopes of the 16.8 ha cell that has been used since 1987 with 3 million $\mathrm{Mg}$ of waste and division with intake of leachate waters and rainfall waters. Reclamation of the landfill cell No. 1 fully protects the environment from the effect of waste deposited in this cell.

- Building the stage I of the landfill cell No. 2: the effect of this task was a new landfill cell with usable surface area of 2.6 ha with drainage system and synthetic sealing. The technologies used for the cell construction meet al the current standards and guarantee a full security of individual environmental components during the functional use.

- Building the composting facility using the closed technology: building the composting plant helped adjust the regional installation of waste management with European standards. This results in the implementation of modern technologies based on aerobic composting in reinforced concrete bioreactors, which allows for the use of the initial phase of intensive composting under hermetic and controlled conditions. The composting plant processes the subscreen fraction from the mixed municipal waste. The post-processing air is cleaned and, if monitoring detects exceeding the permissible parameters, the afterburning system will be switched on automatically. This technological process ensures a $100 \%$ air protection from possible pollutants.

The benefits of the extension of the Waste Management Plant included:

- reduction of harmful emissions to air, land, and waters,

- limitation of the sanitary threat and limitation of the substantial amount of liquor as a result of closure and reclamation of the landfill cell,

- reduction of greenhouse gas emissions as a result of limitation of landfilling of biodegradable waste,

- $\quad$ safe landfilling of waste which is impossible to be recycled (ballast) using a modern landfill cell equipped with facilities that protect all the components of the environment,

- returning of the degraded land (ca. $16.8 \mathrm{ha}$ ) to the environment, used previously for landfilling of waste by means of reclamation.

The ecological effects of the investment include:

- Achievement of the efficiency of the Waste Management Plant in Sobuczyna of up to $116000 \mathrm{Mg} /$ year.

- Limitation of the amount of waste discharged to the landfill site by $32 \%$ (from $68 \%$ in 2009 to $36 \%$ in 2015) 
- Including 150000 people in the municipal waste management system.

Another important ecological investment was limitation of the amount of waste deposited in the environment through implementation of the systematic solution of selective waste collection in the city of Czestochowa. This was possible due to the contract with the Marshall's Office in the Department of Regional Development in Katowice. The net value of the entire project was 5,8 million PLN. This involved the campaign aimed to promote the activities of selective waste collection. The educational campaign helped the community realize how important selective waste collection is and what measurable benefits it can produce to the natural environment. The project included three investment tasks:

- 200 local points of municipal selective waste collection were created. Each point was composed of 3 containers for paper, plastics/metal and glass.

- Five hook containers were purchased as local points of biodegradable waste collection.

- The Stationary Point of Selective Collection of Municipal Waste (SPSZOK) was designed and construed in the area of regional installation of waste management in Sobuczyna. This is a comprehensively equipped facility used to collect and temporary store municipal waste, dangerous waste, post-renovation waste and bulky wastes. Each inhabitant of Czestochowa can supply sorted waste to this facility, such as: postrenovation waste, metal, glass, bulky wastes, plastics, tyres, car windows, used electrical and electronic equipment, dangerous waste, foil and waste paper.

Table 3 presents the levels of municipal waste management achieved by the Community City of Czestochowa in 2017. These results were possible due to the ecological investments made in the area of the enterprise. According to the Silesian Voivodeship Waste Management Plan for 2016-2022, the needs connected with current waste management system in the Region I of the Silesian Voivodeship were diagnosed. They are connected with building and modernization of current installations for processing of green waste and other biodegradable waste. It is also necessary to increase capabilities of these installations as the deficit was observed already in 2016. The investment will be made within the project, consisting in the extension of the composting plant dedicated to green and biodegradable waste with capacity of $15000 \mathrm{Mg} /$ year.

Table 3. The levels for municipal waste management achieved by the City of Czestochowa in 2017 [10]

\begin{tabular}{|l|c|c|}
\hline \multicolumn{1}{|c|}{ Type of management } & $\begin{array}{c}\text { Acceptable } \\
\text { level } \\
{[\%]}\end{array}$ & $\begin{array}{c}\text { Level } \\
\text { reached } \\
{[\%]}\end{array}$ \\
\hline $\begin{array}{l}\text { recycling, preparation for reuse and recovery using other fraction } \\
\text { methods: paper, metals, plastics, glas }\end{array}$ & 20 & 24.58 \\
\hline $\begin{array}{l}\text { recycling, preparation for reuse and recovery by other methods of non- } \\
\text { hazardous construction and demolition waste }\end{array}$ & $\begin{array}{c}\text { Acceptable } \\
\text { level } \\
{[\%]}\end{array}$ & $\begin{array}{c}\text { Level } \\
\text { reached } \\
\text { [\%] }\end{array}$ \\
\hline reduction of biodegradable municipal waste transferred to landfilling
\end{tabular}

\section{Conclusions}

The most important effect of the investments carried out was the extension of the inhabitants of the Northern Subregion of the Silesian Province to an organized waste collection system, thus improving the condition of the natural environment in Czestochowa and throughout the Czestochowa poviat.

Thanks to the implemented projects: 
- the amount of waste sent to the landfill has been reduced. Currently, the landfill is directed primarily to the so-called post-process waste;

- separation in the process of sorting of biodegradable fraction directed to the stabilization process and the fraction containing secondary raw materials and the component for alternative fuel;

- reduction of biodegradable waste to the level required by law;

- separation from municipal waste: large-size waste along with its dismantling; construction waste with crumbling and preparation for re-use; hazardous waste to be disposed of for disposal.

The effect of the implementation of projects is primarily to increase the efficiency of municipal waste treatment and to reduce the inconvenience of the existence of Waste Management Plants for the surrounding population.

\section{References}

1. Program Operacyjny Infrastruktura i Środowisko w województwie śląskim, wrzesień 2013, https://www.wfosigw.katowice.pl/poiisfiles/biuletyn_POIiS 2013.pdf (2013)

2. Plan gospodarki odpadami dla województwa śląskiego na lata 2016-2022, https://bip.slaskie.pl/dokumenty/2016/11/02/1478090442.pdf

3. Jura J., Zasady finansowania przedsięwzięć proekologicznych, Budownictwo o zoptymalizowanym potencjale energetycznym, 1, 15, pp 85-90, (2015)

4. Toruński J., Wyrębek H., Źródła finansowania inwestycji ekologicznych w Polsce, Zeszyty Naukowe Akademii Podlaskiej w Siedlcach, 82, pp 43-63 , (2009)

5. Bień E., Źródła finansowania gospodarki odpadami w gminach województwa śląskiego, Inżynieria i Ochrona Środowiska, 13, 1, pp. 5-15, (2010)

6. Opracowanie własne na podst. PGO Woj. Śląskiego na lata 2014-2020

7. Barczak A., Kowalewska E., Źródła finansowania zadań z zakresu ochrony środowiska w Polsce - przegląd stosowanych rozwiązań, Prawo Budżetowe Państwa i Samorządu, 1, 20, pp. 37-58, (2014)

8. https://rpo.slaskie.pl/

9. https://www.pois.gov.pl/strony/o-programie/zasady/finansowanie/

10. http://www.mos.gov.pl/ 